\title{
DESKRIPSI MOTIVASI BELAJAR FISIKA SISWA KELAS X MIA DI SMAN 9 KOTA JAMBI
}

\author{
Ratna Sari Sitompul ${ }^{1}$, Astalini $^{2}$, dan Alrizal $^{3}$ \\ ${ }^{1,2,3}$ Program Studi Pendidikan Fisika FKIP Universitas Jambi, Jambi, Indonesia \\ E-mail: ratnasarisitompul17@gmail.com, astalinizakir@gmail.com, alrizal91@gmail.com
}

\section{Info Artikel}

Diterima:

13 Agustus 2018

Disetujui:

05 November 2019

Dipublikasikan:

15 Desember 2018

Alamat Korespondensi:

ratnasarisitompul@yahoo.co.id

\begin{abstract}
Abstrak:
Tujuan penelitian ini adalah untuk mendeskripsikan motivasi belajar fisika siswa kelas X MIA di SMAN 9 Kota Jambi. Jenis penelitian ini adalah penelitian deskriptif dengan pendekatan kuantitatif. Populasi penelitian ini adalah siswa kelas X MIA di SMAN 9 Kota Jambi. Teknik pengambilan sampel dalam penelitian ini adalah total sampling. Instrumen penelitian yang digunakan adalah angket motivasi belajar fisika siswa. Jenis data penelitian ini adalah data kuantitatif. Teknik analisis data yang digunakan adalah analisis kuantitatif menggunakan statistik deskriptif. Hasil penelitian ini menunjukkan bahwa motivasi belajar fisika siswa kelas X MIA di SMAN 9 Kota Jambi pada dimensi motivasi intrinsik bersumber dari indikator tekun dalam mengerjakan tugas yang cenderung berada pada kategori tinggi dengan persentase $59,80 \%$ dimana sikap siswa berada pada kategori sering dan pada dimensi motivasi ekstrinsik bersumber dari indikator adanya umpan balik yang cenderung berada pada kategori tinggi dengan persentase $61,76 \%$ dimana sikap siswa berada pada kategori sering.
\end{abstract}

Kata kunci: deskripsi, motivasi belajar, fisika 


\section{Pendahuluan}

Siswa adalah subjek yang melakukan perbuatan belajar. Menurut Dimyati dan $\mathrm{Mu}-$ djiono (2010) siswa belajar karena didorong oleh kekuatan mental yang disebut motivasi belajar. Hal ini sejalan dengan yang dinyatakan oleh Sardiman (2010) bahwa keinginan atau dorongan untuk belajar disebut dengan motivasi belajar.

Motivasi belajar siswa dapat bersumber dari dorongan dalam diri siswa yang disebut motivasi intrinsik dan dapat bersumber dari dorongan yang berasal dari luar diri siswa yang disebut motivasi ekstrinsik (Hamalik, 2011). Menurut Dimyati dan Mudjiono (2010) motivasi belajar dapat tergolong rendah atau tinggi. Apabila motivasi belajar siswa tinggi, siswa akan menunjukkan sikap dan perilaku belajar yang baik seperti siswa menunjukkan semangat yang tinggi dalam melakukan aktivitas belajar, tekun dan ulet dalam melakukan aktivitas belajar sekalipun dalam waktu yang lama, serta tidak mengenal lelah apalagi bosan dalam belajar. Sebaliknya, apabila motivasi belajar siswa rendah, siswa akan menunjukkan sikap dan perilaku belajar yang tidak baik seperti acuh tak acuh dalam belajar, aktivitas belajar dianggap sebagai suatu beban, serta cepat lelah dan bosan dalam belajar (Hadis dan Nurhayati, 2014).

SMAN 9 Kota Jambi merupakan salah satu satuan pendidikan di Kota Jambi yang memiliki jurusan MIA. Fisika merupakan mata pelajaran peminatan akademik untuk siswa yang berada pada jurusan MIA. Berdasarkan observasi awal peneliti terhadap proses pembelajaran fisika yang berlangsung di kelas X MIA 3 SMAN 9 Kota Jambi, terlihat bahwa ada siswa yang bersemangat dalam mengikuti proses pembelajaran fisika dan juga ada siswa yang tidak bersemangat dalam mengikuti proses pembelajaran fisika. Siswa yang bersemangat mengikuti proses pembelajaran fisika memperlihatkan sikap merespon pertanyaan yang guru berikan sebelum siswa lain menjawab. Sedangkan siswa yang tidak bersemangat dalam mengikuti proses pembelajaran fisika memperlihatkan sikap acuh tak acuh ketika guru memberikan pertanyaan.

Motivasi belajar memegang peranan penting dalam memberi gairah, semangat, dan rasa senang dalam belajar (Widoyoko, 2014). Motivasi belajar berfungsi mendorong siswa untuk melakukan perbuatan belajar demi pencapaian tujuan belajar. Motivasi belajar juga berfungsi sebagai pengarah dan penggerak siswa demi pencapaian tujuan belajar (Hamalik, 2011).

Berdasarkan hasil penelitian Ulfah (2015) terdapat hubungan yang positif dan signifikan antara motivasi belajar dengan hasil belajar fisika siswa kelas X di SMAN 10 Banjarmasin. Selain itu, menurut Lestari (2015) terdapat pengaruh signifikan motivasi belajar terhadap prestasi belajar fisika siswa kelas X SMA Negeri di Kota Denpasar dengan sumbangan efektif $12,73 \%$. Hasil penelitian Febrianti (2013) menunjukkan bahwa terdapat pengaruh positif dan signifikan motivasi belajar terhadap pemahaman konsep fisika siswa dengan memberikan kontribusi 35,1\%.

Penelitian ini bertujuan untuk mendeskripsikan motivasi belajar fisika siswa kelas $\mathrm{X}$ MIA di SMAN 9 Kota jambi pada dimensi motivasi intrinsik dan ekstrinsik. Manfaat penelitian ini adalah sebagai dasar penelitian selanjutnya untuk dapat meningkatkan motivasi belajar fisika siswa.

\section{Metode Penelitian}

\section{Tempat dan Waktu Penelitian}

Tempat penelitian adalah SMAN 9 Kota Jambi yang terletak di Jalan Berdikari Kelurahan Payo Selincah Kecamatan Paal Merah. Penelitian dilakukan di kelas X MIA yaitu di kelas X MIA 1, $X$ MIA 2, dan X MIA 3. Pengumpulan data penelitian dilakukan pada tanggal 27 s.d 29 Maret 2018 di semester genap tahun ajaran 2017/2018.

\section{Desain Penelitian}

Jenis penelitian ini adalah penelitian deskriptif. pada penelitian ini peneliti mendeskripsikan motivasi belajar fisika siswa kelas $\mathrm{X}$ MIA di SMAN 9 Kota Jambi pada dimensi motivasi intrinsik dan pada dimensi motivasi ekstrinsik. Peneliti menghimpun fakta tentang motivasi belajar fisika siswa menggunakan angket motivasi belajar fisika siswa. Sehingga, diperoleh data kuantitatif yang perlu dianalisis untuk menghasilkan informasi. Hubungan antara peneliti dan siswa kelas X MIA di SMAN 9 Kota Jambi bersifat independen.

\section{Populasi dan Sampel}

Populasi dalam penelitian ini adalah seluruh siswa kelas X MIA di SMAN 9 Kota Jambi, sebagaimana pada Tabel 1. Peneliti menggunakan teknik pengambilan sampel yaitu total sampling. Peneliti menggunakan total 
sampling karena peneliti ingin hasil penelitian berlaku untuk populasi yaitu siswa kelas $\mathrm{X}$ MIA di SMAN 9 Kota Jambi.

Tabel 1. Populasi Siswa Kelas X MIA di SMAN 9 Kota Jambi

\begin{tabular}{ccc}
\hline Kelas & Nama Kelas & Jumlah Siswa \\
\hline X MIA & X MIA 1 & 34 \\
& X MIA 2 & 34 \\
& X MIA 3 & 34 \\
\hline Total & \multicolumn{2}{c}{ 102 Siswa } \\
\hline \multicolumn{3}{c}{ (Sumber: TU SMAN 9 Kota Jambi) }
\end{tabular}

Teknik Pengumpulan Data

Data yang diperlukan adalah data primer.

Data primer yang diperoleh berupa data motivasi belajar fisika siswa yang diambil dengan menggunakan instrumen penelitian berupa angket.

\section{Instrumen Penelitian}

Peneliti menggunakan indikator motivasi belajar yang dinyatakan oleh ekawarna (2009) dan telah dikembangkan menjadi angket motivasi belajar fisika siswa oleh Nababan (2014) yang terdiri dari 25 item pernyataan. Setiap item pernyataan dinilai dengan skala likert. Adapun kisi-kisi angket motivasi belajar fisika siswa terlihat pada Tabel 2.

Tabel 2. Kisi-Kisi Angket Motivasi Belajar Fisika Siswa

\begin{tabular}{|c|c|c|c|c|}
\hline Dimensi & Indikator & Deskripsi & $\begin{array}{c}\text { No } \\
\text { butir }\end{array}$ & Jumlah \\
\hline Motivasi & 1. Aktivitas & a. Bekerja mandiri & 1 & 1 \\
\hline \multirow[t]{12}{*}{ Intrinsik } & belajar & b. Belajar di luar waktu sekolah & 2 & 1 \\
\hline & yang tinggi & c. Penyusunan jadwal belajar & 3 & 1 \\
\hline & & d. Mengulang pelajaran dirumah & 4 & 1 \\
\hline & 2. Tekun & a. Mencari bahan atau sumber bacaan & 5 & 1 \\
\hline & dalam & b. Memeriksa kelengkapan tugas & 6 & 1 \\
\hline & mengerja- & c. Tidak mudah bosan & 7 & 1 \\
\hline & kan tugas & d. Memperbaiki tugas & 8 & 1 \\
\hline & & e. Terus bekerja & 9 & 1 \\
\hline & 3. Ulet dalam & a. Mengajukan pertanyaan pada guru & 10 & 1 \\
\hline & menghada- & b. Bertanya pada teman & $11-12$ & 2 \\
\hline & pi kesulitan & c. Belajar bersama & 13 & 1 \\
\hline & & d. Diskusi & 14 & 1 \\
\hline Motivasi & 4. Adanya & a. Memberi tujuan belajar & 15 & 1 \\
\hline \multirow[t]{7}{*}{ Ekstrinsik } & informasi & b. Menjelaskan melalui contoh & 16 & 1 \\
\hline & dari guru & $\begin{array}{l}\text { c. Menulis hal-hal yang dianggap } \\
\text { penting }\end{array}$ & 17 & 1 \\
\hline & 5. Adanya & a. Memberi informasi hasil ulangan & $18-20$ & 3 \\
\hline & $\begin{array}{l}\text { umpan } \\
\text { balik }\end{array}$ & $\begin{array}{l}\text { b. Memberi komentar terhadap tugas } \\
\text { latihan/PR }\end{array}$ & 21 & 1 \\
\hline & & c. Memberi kesempatan bertanya & $22-23$ & 2 \\
\hline & 6. Adanya & a. Memberikan pujian & 24 & 1 \\
\hline & penguatan & $\begin{array}{l}\text { b. Membantu menemukan cara-cara } \\
\text { menarik kesimpulan }\end{array}$ & 25 & 1 \\
\hline
\end{tabular}

Validitas dan Reliabilitas

Angket motivasi belajar fisika yang digunakan merupakan angket yang dikembangkan oleh Nababan (2014) yang telah melalui validasi ahli sehingga layak digunakan dan telah diuji coba dengan validitas butir terlihat pada Tabel 3 dan reliabilitas 0,909 dengan kriteria sangat tinggi. 
Tabel 3. Nilai Koefisien Validitas

Instrumen Penelitian

\begin{tabular}{ccc}
\hline $\begin{array}{c}\text { No. } \\
\text { Butir }\end{array}$ & $\begin{array}{c}\text { Nilai Koefisien } \\
\text { Validitas }\end{array}$ & Keterangan \\
\hline 1 & 0,356 & Valid \\
2 & 0,744 & Valid \\
3 & 0,583 & Valid \\
4 & 0,553 & Valid \\
5 & 0,744 & Valid \\
6 & 0,368 & Valid \\
7 & 0,533 & Valid \\
8 & 0,583 & Valid \\
9 & 0,465 & Valid \\
10 & 0,553 & Valid \\
11 & 0,744 & Valid \\
12 & 0,358 & Valid \\
13 & 0,359 & Valid \\
14 & 0,340 & Valid \\
15 & 0,464 & Valid \\
16 & 0,375 & Valid \\
17 & 0,744 & Valid \\
18 & 0,533 & Valid \\
19 & 0,718 & Valid \\
20 & 0,567 & Valid \\
21 & 0,522 & Valid \\
22 & 0,408 & Valid \\
23 & 0,455 & Valid \\
24 & 0,688 & Valid \\
25 & 0,688 & Valid \\
\hline & & Sumber: Nababan (2014)
\end{tabular}

Teknik Analisis Data

Setelah data dari seluruh responden terkumpul peneliti melakukan kegiatan dalam analisis data, sebagai berikut:

1. Mentabulasi data.

Peneliti menggunakan tabel pemindahan untuk distribusi penskoran angket. Pada tabel pemindahan dilakukan proses kuantifikasi untuk mengkonversikan data kualitatif menjadi data kuantitatif. Peneliti menggunakan model lima pilihan (skala lima), yang dituliskan pada Tabel 4.

Tabel 4. Penskoran Alternatif Respon

\begin{tabular}{cc}
\hline Alternatif Respon & Skor \\
\hline Selalu & 5 \\
Sering & 4 \\
Kadang-kadang & 3 \\
Jarang & 2 \\
Tidak Pernah & 1 \\
\hline & Sumber: Widoyoko
\end{tabular}

2. Menganalisis data.

Peneliti menganalisis data untuk melakukan perhitungan skor maksimal, skor minimal, mean, standar deviasi, dan persentase kategori motivasi belajar fisika siswa. Analisis data dilakukan dengan menggunakan Microsoft Excel dan rumus manual.

Teknik analisis data penelitian ini adalah analisis kuantitatif dengan menggunakan statistik deskriptif. Penarikan kesimpulan pada statistik deskriptif hanya ditujukan pada kumpulan data yang ada. Statistik deskriptif yang digunakan adalah ukuran pemusatan yaitu mean, ukuran penyebaran yaitu standar deviasi, dan persentase kategori.

Mean dirumuskan pada Persamaan (1).

$$
\bar{X}=\frac{\sum f \cdot X}{\sum f}
$$


Keterangan:

$$
\begin{array}{ll}
\bar{X} & =\text { mean } \\
X & =\text { data } \\
f & =\text { frekuensi data }
\end{array}
$$

Standar deviasi dirumuskan pada Persamaan (2).

$$
s=\sqrt{\frac{\sum f(X-\bar{X})^{2}}{n}}
$$

Keterangan:

$$
\begin{aligned}
& s^{2} \quad=\text { varian } \\
& S \quad=\text { standar deviasi } \\
& (X-\bar{X})^{2} \quad=\text { kuadrat simpangan } \\
& \mathrm{n} \quad=\text { banyak data } \\
& f \quad=\text { frekuensi data }
\end{aligned}
$$

Analisis data yang diperoleh dari angket dapat didasarkan pada rerata skor jawaban responden, maka skor yang terkumpul dapat dikategorikan berskala interval. Untuk menentukan jarak interval digunakan Persamaan (3).

$$
i=\frac{\text { skor tertinggi }- \text { skor terendah }}{\text { jumlah kelas interval }}
$$

Keterangan:

$i \quad=$ jarak interval

Sehingga dapat disusun tabel kategori sikap responden pada indikator pernyataan angket, berdasarkan rerata skor jawaban responden yang digunakan seperti pada Tabel 5 dan juga dapat disusun tabel kategori motivasi belajar fisika siswa, berdasarkan rerata skor jawaban responden yang digunakan seperti pada Tabel 6 .

Tabel 5. Kategori Sikap Responden pada Indikator Pernyataan

\begin{tabular}{ccc}
\hline No. & $\begin{array}{c}\text { Interval Rerata } \\
\text { Skor }\end{array}$ & Kategori \\
\hline 1. & $4,21 \leq \bar{X} \leq 5,0$ & Selalu (SL) \\
2. & $3,41 \leq \bar{X} \leq 4,2$ & Sering (SR) \\
3. & $2,61 \leq \bar{X} \leq 3,4$ & Kadang- \\
Kadang (KK) \\
4. & $1,81 \leq \bar{X} \leq 2,6$ & Jarang (JR) \\
5. & $1,0 \leq \bar{X} \leq 1,8$ & Tidak Pernah \\
(TP)
\end{tabular}

Tabel 6. Kategori Motivasi Belajar Fisika Siswa

\begin{tabular}{ccc}
\hline No. & $\begin{array}{c}\text { Interval Rerata } \\
\text { Skor }\end{array}$ & Kategori \\
\hline 1. & $4,21 \leq \bar{X} \leq 5,0$ & Sangat Tinggi \\
(ST) \\
2. & $3,41 \leq \bar{X} \leq 4,2$ & Tinggi (T) \\
3. & $2,61 \leq \bar{X} \leq 3,4$ & Sedang (S) \\
4. & $1,81 \leq \bar{X} \leq 2,6$ & Rendah (R) \\
5. & $1,0 \leq \bar{X} \leq 1,8$ & $\begin{array}{c}\text { Sangat Rendah } \\
\text { (SR) }\end{array}$ \\
\hline \multicolumn{2}{r}{ Sumber: Widoyoko }
\end{tabular}

Untuk mencari persentase kategori motivasi belajar digunakan Persamaan (4).

$\%$ kategori $=\frac{\text { frekuensi } \text { kategori }}{\text { jumlah responden }} \times 100 \%$

3. Menyajikan data dalam bentuk tabel atau grafik.

4. Menginterpretasikan data.

Prosedur Penelitian

Prosedur penelitian adalah langkahlangkah atau urutan yang harus dilalui atau dikerjakan oleh suatu penelitian. Secara garis besar, prosedur penelitian terdiri dari tiga tahap sebagaimana Gambar 1.

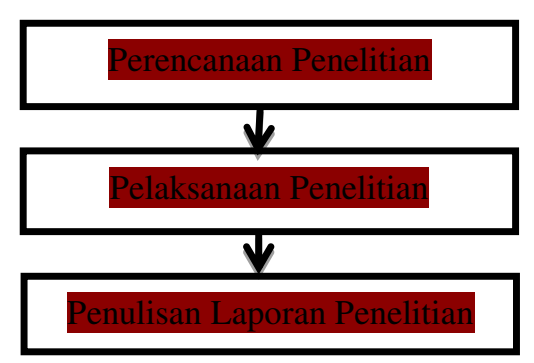

Gambar 1. Bagan Prosedur Penelitian

\section{Hasil dan Pembahasan}

Hasil

Data diperoleh dari hasil sebaran angket kepada 102 siswa SMAN 9 Kota Jambi. Berikut data hasil yang diperoleh dari penyebaran angket motivasi belajar fisika siswa pada Tabel 7 . 
Tabel 7. Hasil Analisis Statistik Deskriptif

\begin{tabular}{lcccccc}
\hline \multirow{2}{*}{$\begin{array}{c}\text { Statistik } \\
\text { Deskriptif }\end{array}$} & \multicolumn{3}{c}{ Motivasi Intrinsik } & \multicolumn{3}{c}{ Motivasi Ekstrinsik } \\
\cline { 2 - 7 } & $\mathbf{1}$ & $\mathbf{2}$ & $\mathbf{3}$ & $\mathbf{4}$ & $\mathbf{5}$ & $\mathbf{6}$ \\
\hline Standar Deviasi & 0,63 & 0,54 & 0,56 & 0,55 & 0,54 & 0,86 \\
Skor Max & 5 & 5 & 5 & 5 & 5 & 5 \\
Skor Min & 1,5 & 2 & 2,4 & 3 & 2,17 & 1,5 \\
Mean & 3,06 & 3,87 & 3,77 & 4,22 & 3,82 & 3,89 \\
\hline
\end{tabular}

Keterangan:

Motivasi Intrinsik

1. Indikator aktivitas belajar yang tinggi

2. Indikator tekun dalam mengerjakan tugas

3. Indikator ulet dalam menghadapi kesulitan

4. Motivasi Ekstrinsik

5. Indikator adanya informasi dari guru

6. Indikator adanya umpan balik

7. Indikator adanya penguatan

Berdasarkan penggolongan kategori sikap responden dengan skala interval (Tabel 5), nilai Mean pada Tabel 7 menunjukkan bahwa sikap responden pada dimensi motivasi intrinsik meliputi indikator aktivitas belajar tinggi cenderung berada pada kategori kadang-kadang, indikator tekun dalam mengerjakan tugas cenderung berada pada kategori sering, dan indikator ulet dalam menghadapi kesulitan cenderung berada pada kategori sering. Pada dimensi motivasi ekstrinsik meliputi indikator adanya informasi dari guru cenderung berada pada kategori selalu, indikator adanya umpan balik cenderung berada pada kategori sering, dan indikator adanya penguatan cenderung berada pada kategori sering.

Berdasarkan penggolongan kategori motivasi belajar fisika siswa dengan menggunakan skala interval sebagaimana Tabel 6, diperoleh persentase kategori motivasi belajar fisika siswa kelas X MIA di SMAN 9 Kota Jambi dari 102 siswa seperti pada Gambar 2.

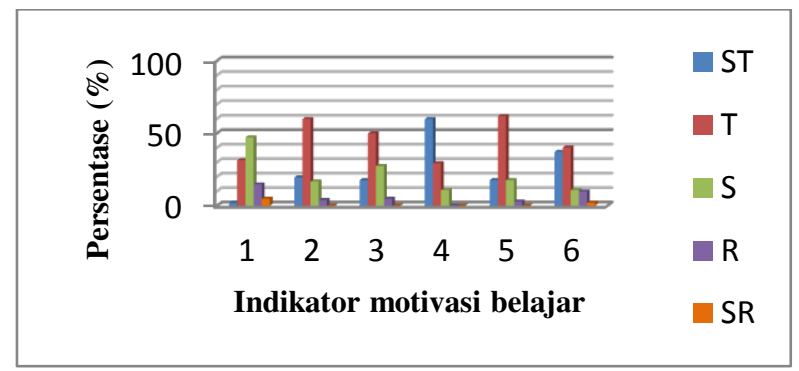

Gambar 2. Grafik Kategori Motivasi Belajar Fisika Siswa Kelas X MIA di SMAN 9 Kota Jambi
Berdasarkan Gambar 2 kategori motivasi belajar fisika siswa pada dimensi motivasi intrinsik yaitu indikator aktivitas belajar yang tinggi cenderung berada pada kategori sedang, indikator tekun dalam mengerjakan tugas cenderung berada pada kategori tinggi, dan indikator ulet dalam menghadapi kesulitan cenderung berada pada kategori tinggi. Pada dimensi motivasi ekstrinsik yaitu indikator adanya informasi dari guru cenderung berada pada kategori sangat tinggi, indikator adanya umpan balik cenderung berada pada kategori tinggi, dan indikator adanya penguatan cenderung berada pada kategori tinggi.

\section{Pembahasan}

Permasalahan yang dideskripsikan dalam penelitian ini adalah motivasi belajar fisika siswa kelas X MIA di SMAN 9 Kota Jambi pada dimensi motivasi intrinsik meliputi indikator aktivitas belajar yang tinggi, indikator tekun dalam mengerjakan tugas, dan indikator ulet dalam menghadapi kesulitan. Serta motivasi belajar fisika siswa kelas X MIA di SMA N 9 Kota Jambi pada dimensi motivasi ekstrinsik meliputi indikator adanya informasi dari guru, indikator adanya umpan balik, dan indikator adanya penguatan.

Data diperoleh dari responden yang berjumlah 102 siswa, yang diambil menggunakan teknik pengambilan sampel yaitu total sampling. Total sampling merupakan teknik pengambilan sampel yang menggunakan seluruh anggota populasi (Usman dan Akbar, 2015). Peneliti menggunakan total sampling karena peneliti ingin hasil penelitian berlaku untuk populasi yaitu siswa kelas X MIA di SMAN 9 Kota Jambi. Menurut Arikunto (2013) penelitian populasi dilakukan apabila peneliti ingin melihat semua liku-liku yang ada di dalam populasi.

Untuk mengumpulkan data penelitian, peneliti menggunakan instrumen penelitian berupa angket. Angket yang digunakan adalah angket motivasi belajar fisika siswa yang diadopsi dari Nababan (2014), terdiri dari 25 item pernya- 
taan yang dikelompokkan menjadi 14 item pernyataan pada dimensi motivasi intrinsik meliputi 4 item untuk mendeskripsikan indikator aktivitas belajar yang tinggi, 5 item untuk mendeskripsikan indikator tekun dalam mengerjakan tugas, dan 5 item untuk mendeskripsikan indikator ulet dalam menghadapi kesulitan. Serta 11 item pernyataan pada dimensi motivasi ekstrinsik meliputi 3 item untuk mendeskripsikan indikator adanya informasi dari guru, 6 item untuk mendeskripsikan indikator adanya umpan balik, dan 2 item untuk mendeskripsikan indikator adanya penguatan.

Data yang diperoleh melalui angket merupakan data kualitatif. Agar dapat dianalisis menggunakan statistik maka dilakukan proses kuantifikasi menggunakan penskoran dengan skala likert, sebagaimana pada Tabel 4. Menurut Sudijono (2008) proses kuantifikasi merupakan proses mengkonversikan data kualitatif menjadi data kuantitatif.

Setelah diperoleh data kuantitatif, maka dilakukan perhitungan pada respon jawaban responden untuk memperoleh rerata skor jawaban responden pada indikator aktivitas belajar yang tinggi, indikator tekun dalam mengerjakan tugas, indikator ulet dalam menghadapi kesulitan, indikator adanya informasi dari guru, indikator adanya umpan balik, dan indikator adanya penguatan untuk dapat menentukan skor maksimal, skor minimal, dan untuk melakukan perhitungan mean dan standar deviasi.

Serta dilakukan penggolongan kategori motivasi belajar fisika siswa berdasarkan skala interval sebagaimana yang dinyatakan oleh Widoyoko (2014) berdasarkan rerata skor jawaban responden, agar dapat menentukan pengolongan kategori motivasi belajar fisika siswa dan melakukan perhitungan persentase kategori motivasi belajar fisika siswa pada indikator aktivitas belajar yang tinggi, indikator tekun dalam mengerjakan tugas, indikator ulet dalam menghadapi kesulitan, indikator adanya informasi dari guru, indikator adanya umpan balik, dan indikator adanya penguatan.

Berdasarkan hasil penelitian yang diperoleh, tinggi atau rendahnya motivasi belajar siswa dapat diukur dari indikator motivasi belajar sebagaimana yang dinyatakan oleh Ekawarna (2009), yaitu:

1. Indikator aktivitas belajar yang tinggi

Motivasi belajar fisika siswa pada indikator aktivitas belajar yang tinggi cenderung berada pada kategori sedang dengan persentase 47,06\% dimana sikap siswa cenderung berada pada kategori kadang-kadang. Hasil penelitian ini sejalan dengan yang dinyatakan oleh Hadis dan Nurhayati (2014) bahwa siswa yang memiliki motivasi belajar tinggi menunjukkan sikap dan perilaku belajar yang baik berupa melakukan aktivitas belajar. Bentuk-bentuk sikap dan perilaku yang ditunjukkan siswa yang berada pada kategori motivasi belajar sedang untuk indikator aktivitas belajar yang tinggi adalah siswa kadang-kadang belajar dan mengerjakan tugas fisika secara mandiri, siswa kadang-kadang memanfaatkan waktu senggang diluar jam sekolah untuk belajar fisika, siswa kadang-kadang menyusun dan melaksanakan jadwal belajar di rumah, serta siswa kadangkadang mengulang kembali pelajaran fisika yang sudah diajarkan di sekolah.

2. Indikator tekun dalam mengerjakan tugas Motivasi belajar fisika siswa pada indikator tekun dalam mengerjakan tugas cenderung berada pada kategori tinggi dengan persentase $59,80 \%$ dimana sikap siswa cenderung berada pada kategori sering. Hasil penelitian ini sejalan dengan yang dinyatakan oleh Hadis dan Nurhayati (2014) bahwa siswa yang memiliki motivasi belajar tinggi menunjukkan sikap dan perilaku belajar yang baik berupa tekun dalam melakukan aktivitas belajar. Bentuk-bentuk sikap dan perilaku yang ditunjukkan siswa yang berada pada kategori motivasi belajar tinggi untuk indikator tekun dalam mengerjakan tugas adalah siswa sering berusaha mencari bahan atau sumber belajar yang dianjurkan guru, siswa sering memeriksa kelengkapan tugas fisika sebelum dikumpulkan, siswa sering tidak mudah bosan jika belajar tentang mata pelajaran fisika, siswa sering berusaha memperbaiki tugas fisika yang diberikan guru jika tugas tersebut salah, siswa sering akan terus bekerja menyelesaikan tugas atau PR fisika yang diberikan guru sampai benar-benar sempurna.

3. Indikator ulet dalam menghadapi kesulitan Motivasi belajar fisika siswa pada indikator ulet dalam menghadapi kesulitan cenderung berada pada kategori tinggi dengan persentase $50 \%$ dimana sikap siswa cenderung berada pada kategori sering. Hasil penelitian ini sejalan dengan yang dinyatakan oleh Hadis dan Nurhayati (2014) bahwa siswa yang memiliki motivasi belajar tinggi menunjukkan 
sikap dan perilaku belajar yang baik berupa ulet dalam melakukan aktivitas belajar. Bentuk-bentuk sikap dan perilaku yang ditunjukkan siswa yang berada pada kategori motivasi belajar tinggi untuk indikator ulet dalam menghadapi kesulitan adalah siswa sering bertanya kepada guru jika siswa tidak mengerti tentang materi pelajaran fisika yang diajarkan, siswa sering bertanya kepada teman tentang materi pelajaran fisika yang belum siswa mengerti, siswa sering tidak merasa malu jika siswa harus bertanya kepada siapapun, siswa sering belajar bersama teman untuk mengerjakan tugas atau PR fisika yang sulit, serta siswa sering mendiskusikan hal-hal yang siswa anggap sulit.

4. Indikator adanya informasi dari guru

Motivasi belajar fisika siswa pada indikator adanya informasi dari guru cenderung berada pada kategori sangat tinggi dengan persentase $59,80 \%$ dimana sikap siswa cenderung berada pada kategori selalu. Hasil Penelitian ini sejalan dengan yang dinyatakan oleh Hamalik (2011) dengan memberikan stimulus maka siswa akan merespon. Stimulus dan respon akan menimbulkan kebiasaan-kebiasaan otomatis pada belajar. Selain itu, menurut Hamalik (2009) guru perlu melakukan upaya pemberian harapan, diantaranya rumusan tujuan-tujuan pembelajaran sekhusus mungkin. Bentuk-bentuk sikap dan perilaku yang ditunjukkan siswa yang berada pada kategori motivasi belajar sangat tinggi untuk indikator adanya informasi dari guru adalah jika guru fisika menjelaskan kompetensi yang akan dicapai, siswa selalu berusaha memahaminya dan berkeinginan mencapinya; siswa selalu termotivasi oleh contoh-contoh yang diberikan guru; jika guru fisika menulis catatan-catatan penting di papan tulis, siswa selalu segera menyalinnya dalam buku siswa.

5. Indikator adanya umpan balik

Motivasi belajar fisika siswa pada indikator adanya umpan balik cenderung berada pada kategori tinggi dengan persentase $61,76 \%$ dimana sikap siswa cenderung berada pada kategori sering. Hasil Penelitian ini sejalan dengan yang dinyatakan oleh Hamalik (2011) dengan memberikan stimulus maka siswa akan merespon. Stimulus dan respon akan menimbulkan kebiasaan-kebiasaan otomatis pada belajar. Bentuk-bentuk sikap dan perilaku yang ditunjukkan siswa yang berada pada kategori motivasi belajar tinggi untuk indikator adanya umpan balik adalah jika guru fisika mengumumkan hasil ulangan di depan kelas, siswa sering lebih bersemangat lagi dalam belajar; jika nilai hasil ulangan fisika siswa rendah, siswa sering berkeinginan kuat untuk mencapai nilai tinggi pada ulangan berikutnya; jika nilai hasil ulangan fisika siswa tinggi, siswa sering berusaha mempertahankannya dengan belajar lebih giat lagi; jika guru fisika mengembalikan tugas atau PR dengan beberapa catatan, siswa sering berusaha memperhatikan catatan tersebut untuk perbaikan tugas atau PR selanjutnya; jika guru fisika memberi kesempatan kepada siswa untuk bertanya, siswa sering memanfaatkan kesempatan untuk bertanya; jika guru memberi pertanyaan, siswa sering berusaha menjawab sebelum siswa lain menjawabnya.

6. Indikator adanya penguatan

Motivasi belajar fisika siswa pada indikator adanya penguatan cenderung berada pada kategori tinggi dengan persentase 40,20\% dimana sikap siswa cenderung berada pada kategori sering. Hasil penelitian ini sejalan dengan yang dinyatakan oleh Hamalik (2009) guru dituntut memberikan penguatan ekstra dan bimbingan agar siswa mau belajar lebih keras dengan penuh perhatian melaksanakan tugas-tugas belajar siswa. Bentuk-bentuk sikap dan perilaku yang ditunjukkan siswa yang berada pada kategori motivasi belajar tinggi untuk indikator adanya penguatan adalah jika guru fisika memberikan pujian terhadap pertanyaan, jawaban, tugas atau PR dan hasil ulangan siswa, semangat belajar siswa sering semakin meningkat; jika guru fisika membantu siswa bagaimana cara-cara menarik kesimpulan tentang materi yang sedang dibahas, maka cara-cara tersebut sering siswa gunakan dalam pembahasan materi lainnya.

Hasil penelitian ini sejalan dengan hasil penelitian Long (2013) yang menyimpulkan bahwa siswa yang memiliki motivasi tinggi akan menujukkan sikap positif dalam belajar dan guru harus mengambil langkah-langkah untuk membangkitkan motivasi belajar siswa. Hasil penelitian Bakar (2014) menyimpulkan bahwa motivasi sebagai salah satu faktor internal hanya dapat diaktifkan oleh siswa itu sendiri, tetapi stimulus dapat dimulai dari luar yang biasanya berasal dari guru. Selain itu, Emda (2017) menyimpulkan bahwa Munculnya motivasi tidak semata-mata 
dari diri siswa sendiri tetapi guru harus melibatkan diri untuk memotivasi belajar siswa.

Motivasi belajar berfungsi mendorong siswa untuk melakukan perbuatan belajar demi pencapaian tujuan belajar. Motivasi belajar juga berfungsi sebagai pengarah dan penggerak siswa demi pencapaian tujuan belajar. Oleh sebab itu, guru perlu melakukan berbagai upaya untuk membangkitkan motivasi belajar siswa. Menurut Rohani (2010) beberapa cara yang dapat dilakukan guru untuk membangkitkan motivasi belajar siswa adalah:

1. Mengajar yang bervariasi.

2. Mengadakan pengulangan informasi.

3. Memberi stimulus baru, misalnya melalui pertanyaan-pertanyaan kepada siswa.

4. Memberi kesempatan siswa untuk menyalurkan keinginan belajarnya.

5. Menggunakan media dan alat bantu yang menarik perhatian siswa.

\section{Simpulan dan Saran}

Simpulan

Berdasarkan hasil penelitian yang diperoleh, yang didasarkan pada penggolongan kategori sikap responden dan kategori motivasi belajar fisika siswa dengan menggunakan skala interval dapat disimpulkan bahwa motivasi belajar fisika siswa kelas X MIA di SMAN 9 Kota Jambi:

1. Pada dimensi motivasi intrinsik bersumber dari indikator tekun dalam mengerjakan tugas yang cenderung berada pada kategori tinggi dengan persentase $59,80 \%$ dimana sikap siswa berada pada kategori sering.

2. Pada dimensi motivasi ekstrinsik bersumber dari indikator adanya umpan balik yang cenderung berada pada kategori tinggi dengan persentase $61,76 \%$ dimana sikap siswa berada pada kategi sering.

Saran

Berdasarkan hasil penelitian, maka disarankan untuk dilakukan penelitian lanjut untuk meningkatkan motivasi belajar fisika siswa. Indikator motivasi belajar yang peneliti sarankan untuk ditingkatkan adalah aktivitas belajar yang tinggi. Aktivitas belajar yang tinggi dapat ditingkatkan dengan menggunakan media pembelajaran fisika seperti multimedia interaktif pembelajaran fisika.

\section{Daftar Pustaka}

Arikunto, S. (2013). Prosedur Penelitian Suatu Pendekatan Praktik. Jakarta: Rineka Cipta.

Bakar, R. (2014). The Effect Of Learning Motivation On Student's Productive Competencies In Vocational High School, West Sumatra. International Journal of Asian Social Science, 4(6), 722-732.

Dimyati dan Mudjiono. (2010). Belajar dan Pembelajaran. Jakarta: Rineka Cipta.

Ekawarna. (2009). Penelitian Tindakan Kelas. Jakarta: Gaung Persada Press.

Emda, A. (2017). Kedudukan Motivasi Belajar Siswa dalam Pembelajaran. Lantanida Journal, 5(2), 172-182.

Febrianti, M. (2013). Pengaruh Motivasi Belajar dan Keterampilan Proses Sains Terhadap Pemahaman Konsep Fisika Siswa. Pembelajaran Fisika, 1(2), 55-66.

Hadis, A. dan Nurhayati B. (2014). Psikologi dalam Pendidikan. Bandung: Alfabeta.

Hamalik, O. (2009). Kurikulum dan Pembelajaran. Jakarta: Bumi Aksara.

Hamalik, O. (2011). Proses Belajar Mengajar. Jakarta: Bumi Aksara.

Lestari, A. D. (2015). Pengaruh Tingkat Kecemasan dan Motivasi Belajar Terhadap Prestasi Belajar Fisika. Jurusan Pendidikan Fisika, 2(1).

Long, C., Ming, Z., dan Chen, L. (2013). The Study of Student Motivation on English Learning in Junior Middle School - A Case Study of No.5 Middle School in Gejiu. Canadian Center of Science and Education, 6(9), 136-145.

Nababan, D. E.( 2014). Penerapan Model Pembelajaran ARIAS Terintegratif Untuk Meningkatkan Motivasi Belajar Siswa Kelas XI MIA 1 SMA Negeri 6 Kota Jambi, 
Skripsi, tidak dipublikasikan. Universitas Jambi.

Rohani, A. (2010). Pengelolaan Pengajaran. Jakarta: Rineka Cipta.

Sardiman, A. M. (2010). Interaksi dan Motivasi Belajar Mengajar. Jakarta: Rajawali Pers.

Sudijono, A. (2008). Pengantar Statistik Pendidikan. Jakarta: Rajawali Pers.

Ulfah, Y. (2015). Hubungan Antara Minat dan Motivasi dengan Hasil Belajar Fisika Siswa Kelas X SMAN 10 Banjarmasin. Pendidikan Fisika, 3(2), 203-213.

Usman, H. dan Akbar, R. P. S. (2015). Pengantar Statistika. Jakarta: Bumi Aksara.

Widoyoko, S. E. P. (2014). Teknik Penyusunan Instrumen Penelitian. Yogyakarta: Pustaka Pelajar. 